\begin{tabular}{|l|l|l||}
\hline \multicolumn{2}{|c|}{ PublisherInfo } \\
\hline \hline PublisherName & $:$ & BioMed Central \\
\hline \hline PublisherLocation & $:$ & London \\
\hline \hline PublisherImprintName & $:$ & BioMed Central \\
\hline \hline
\end{tabular}

\title{
Wellcome Trust buys Crick's archives
}

\begin{tabular}{||l|l|l||}
\hline \multicolumn{2}{|c|}{ ArticleInfo } \\
\hline \hline ArticleID & $:$ & 4278 \\
\hline \hline ArticleDOI & $:$ & $10.1186 /$ gb-spotlight-20011217-01 \\
\hline \hline ArticleCitationID & $:$ & spotlight-20011217-01 \\
\hline \hline ArticleSequenceNumber & $:$ & 349 \\
\hline \hline ArticleCategory & $:$ & Research news \\
\hline \hline ArticleFirstPage & $:$ & 1 \\
\hline \hline ArticleLastPage & $:$ & 4 \\
\hline \hline & & RegistrationDate : 2001-12-17 \\
ArticleHistory & $:$ & OnlineDate $\quad$ 2001-12-17 \\
\hline \hline ArticleCopyright & $:$ & BioMed Central Ltd2001 \\
\hline \hline ArticleGrants & $:$ & \\
\hline \hline ArticleContext & $:$ & 130592211 \\
\hline \hline
\end{tabular}


Early in 2002, a rather unusual delivery will be made to The Wellcome Trust library in London. Eleven filing cabinets stuffed with papers containing some of the most valuable scientific data and research of the 20th century will arrive and the long process of cataloguing will begin. What will emerge in the end, it's hoped, is a publicly accessible archive of the work of Francis Crick, the British scientist who, along with James Watson, discovered the structure of DNA in 1953.

The aim is to make as much as possible of this national scientific treasure available online to those who want an insight into Crick, his work and the process by which he and Watson arrived at their landmark findings on DNA. Crick has been described as one of the outstanding British scientific figures of the last century and his DNA work, in the words of the Wellcome Trust, is "widely recognized as one of the defining and enabling moments in the history of human achievement".

Although DNA was first discovered in 1869, it was Crick and Watson's description of its double-helix structure that paved the way for the eventual sequencing of the entire human genome. In 1962, Crick and Watson - along with physician Maurice Wilkins - received the Nobel Prize for Physiology or Medicine for their work. So it is with some degree of satisfaction that, on 6 December 2001, the Wellcome Trust (a UK based charitable foundation that aims to advance biomedical research) announced it had succeeded in securing Crick's papers using a grant of £904,000 given by the Heritage Lottery Fund - a body that uses National Lottery money to fund projects deemed vital for the protection of national heritage. Together with another $£ 904,000$ of its own money, the Trust has the financial wherewithal to ensure the archive - currently residing with Crick in California - is not lost to the nation.

But why is it so important to preserve the papers and, 50 years on, can Crick's work on DNA offer any new insights that might progress today's research? Until the files arrive, the Wellcome Trust said that it's hard to know exactly what they contain. But it's known that Crick has kept records of correspondence, laboratory notebooks and manuscripts for published articles and books. These cover the breakthrough period in the early 1950s when the DNA structure was discovered, together with all Crick's subsequent work in molecular biology and neuroscience. The Trust has proposed the Crick archive - in financial terms its biggest single acquisition - will sit well with the 600,000 books and journals already stocked in itsLibrary for the History and Understanding of Medicine, which is used by more than 30,000 people a year. "Through the library, Crick's collection will be permanently accessible to the public and we are delighted it has not fallen into private hands," said David Pearson, head of the library. "Whether his papers will continue to advance research and knowledge in this area is hard to say. But my sense of Crick and his work is that he did not just make a very important breakthrough in discovering the structure of DNA, but that he was a major figure - and a key thinker - in the development of molecular biology in the 1950s and 1960s." Pearson believes the archive will prove to be much more than a lifeless record of Crick's work on DNA. It will also provide a valuable insight into his thought processes, the motivational factors the drove him forward and the significance of the DNA work in terms of today's rapid advances in human genomics. "We'll have a permanent record of his thought processes and the way in which his thinking was developing and that seems to be something people will want to know about. Whether people will go back to his papers and discover some new breakthrough is more tenuous. It's more a feeling that this was really key stuff in its time and very much shaped where we are today with genome work. It will attract people who are interested in the history of 
science and medicine and that's generally a growth area of activity. People are interested in Crick as a person and as a man and I would guess that in decades to come it's likely that biographers will be interested in him too."

Part of the objective for the Trust will be to engage public interest in Crick's work. Pearson said it would be investigating ways to communicate the message that, although it took place half a century ago, his DNA discovery still affects us all today. Discussions are already underway on how the double helix image could be used as part of that strategy. "The double helix is an icon already, you see it everywhere," Pearson added. "We'll be thinking of ways of engaging the double helix and asking artists to come up with some interpretations of it. We want to get across to the public what an important body of work this was, that it has profoundly affected the way in which science is developing and that there are all these applications that have emerged."

After several months of negotiation to secure Crick's archive, it will take many more to sift through the tens of thousands of documents involved. It's not anticipated that anything will appear - either in the library itself or on-line - until the end of 2002. In the meantime, said Pearson, researchers who need urgent access to Crick's files may be able to do so by contacting the library. Crick himself is reported to "extremely supportive" of the Wellcome Trust initiative, particularly as it ensures free access to his research. "I couldn't think of a better place for my papers to go. The World's scientists and medical historians can't all make it over to my office in the United States but they will soon all have unlimited access to my archives at the Wellcome Library."

\section{References}

1. The Wellcome Trust, [http://www.wellcome.ac.uk/en/1/hme.html]

2. Francis Crick -a biography, [http://www.nobel.se/medicine/laureates/1962/crick-bio.html]

3. James Watson - a biography, [http://www.nobel.se/medicine/laureates/1962/watson-bio.html]

4. Maurice Wilkins - a biography, [http://www.nobel.se/medicine/laureates/1962/wilkins-bio.html]

5. The Nobel Prize in Physiology or Medicine, [http://www.nobel.se/medicine/index.html]

6. Heritage Lottery Fund, [http://www.hlf.org.uk/]

7. The National Lottery, [http://www.national-lottery.co.uk/]

8. The Library for the History and Understanding of Medicine, [http://www.wellcome.ac.uk/en/library/ homlib/HOMlib.html]

9. Francis Crick - The Salk Institute for Biological Studies, [http://www.salk.edu/faculty/crick.html]

This PDF file was created after publication. 
(C) 2009-2013. SPi Global, Chennai, India. All rights reserved. 